\title{
Caries prevalence among Brazilian indigenous population of urban areas based on the 2010 National Oral Health Survey
}

\author{
Prevalência de cárie na população indígena Brasileira de áreas \\ urbanas com base no levantamento de Saúde Bucal Nacional - 2010
}

Kênia Cristina de Oliveira Miranda ${ }^{1}$

Tiago Araújo Coelho de Souza ${ }^{1}$

Soraya Coelho Leal ${ }^{1}$

${ }^{1}$ Departamento de Odontologia, Universidade de Brasília. Campus Universitário Darcy Ribeiro, Asa Norte. 70000-000

Brasília DF Brasil.

mirandakenia@hotmail.com

\begin{abstract}
It is important to have an epidemiological understanding of oral diseases among indigenous persons, in order to contribute with the organization of health services for these populations. The SB Brasil 2010 database was used to compare the prevalence of dental caries among 308 self-identified indigenous and 37,211 non-indigenous individuals from urban areas, in the following age/age-groups: 5, 12, 15-19, 35-44, 6574. The study also analyzed the effect of the complex sample design and the sample weight in the outcomes. Kruskal-Wallis, Wilcoxon Scores (Rank Sums), logistic and multiple linear regressions were used for statistical analysis. The mean $\mathrm{dmft}$ index for indigenous and non-indigenous children aged five were $4.02 \pm 4.01$ and $2.41 \pm 3.35$, respectively, and $46 \%$ of non-native and $30.8 \%$ of native children were caries-free. The mean DMFT for indigenous and non-indigenous were $10.90 \pm$ 11.69 and $10.93 \pm 11.58$, respectively, for all age groups when not taking into account the sample weight effect. When considering the complex sample design and the sample weight effect, the study found a statistical significant difference. The results lend credence to suspicions that in Brazil there are disparities in the patterns of caries between self-identified indigenous and non-indigenous individuals.
\end{abstract}

Key words Caries, Epidemiology indigenous, Oral health
Resumo É importante ter uma compreensão epidemiológica das doenças orais entre as populações indígenas, a fim de contribuir com a organização dos serviços de saúde para essas populações. $O$ banco de dados SB Brasil 2010 foi utilizado para comparar a prevalência de cárie entre os 308 autoidentificados indígenas e 37.211 indivíduos não indigenas de áreas urbanas, nas idades/grupos etários: 5, 12, 15-19, 35-44, 65-74. O estudo também analisou o efeito do desenho amostral complexo e o peso da amostra nos resultados. Kruskal-Wallis, Wilcoxon Scores (Rank Sums), regressão logistica e linear múltipla foram utilizados para análise estatística. $O$ índice ceo-d médio para crianças indígenas e não indígenas com idade de cinco foram 4,02 $\pm 4,01$ e 2,41 $\pm 3,35$, respectivamente, $e$ $46 \%$ dos não nativos e $30,8 \%$ das crianças nativas estavam livres de cárie. A média CPOD para indígenas e não indígenas foram 10,90 $\pm 11,69$ e 10,93 $\pm 11,58$, respectivamente, para público em geral, quando não levando em conta o efeito do peso da amostra. Ao considerar o desenho amostral complexo e o efeito do peso da amostra, o estudo encontrou uma diferença estatisticamente significativa. Os resultados dão crédito às suspeitas de que no Brasil existem disparidades nos padrões de cárie entre indivíduos indígenas e não indígenas autoidentificados.

Palavras-chave Cárie, Epidemiologia indígena, Saúde bucal 


\section{Introduction}

According to the United Nations, due to the diversity of indigenous people worldwide, a modern understanding of the term "indigenous" based on self-identification and recognition by a community with distinct social, environmental, economic, historical, and political structures is preferred instead of an official definition ${ }^{1}$. In Brazil, individuals who identify themselves and are identified as belonging to an ethnic group whose cultural characteristics distinguish them from the national society are considered indigenous $^{2}$. From this perspective, ethnicity should be understood as the perception of being part of a group of people who share certain characteristics, in relation to special cultural traditions and ancestral origins ${ }^{3}$. However, when this concept is applied in health inequalities research, race/ ethnicity and social class are concepts that are strongly related ${ }^{4}$.

It is known that epidemiological surveys, when conducted regularly and with high methodological rigor, are the basis for planning and organizing health services ${ }^{5}$. However, there is a lack of knowledge regarding oral health epidemiology among the indigenous populations in Brazil. Frequently, studies of these populations are cross-sectional include small samples, do not take into consideration sample weights neither the effect of complex sample design and often emphasize specific ethnic groups ${ }^{6}$. As a consequence, they place these individuals in a situation of epidemiological invisibility.

The National Demographic Census conducted in Brazil in 2010 found that among the 896,917 indigenous individuals living in Brazil, $63.8 \%$ resided in rural areas. The Census also identified 375 ethnic groups that speak 274 different languages ${ }^{7}$. The fact that these groups are geographically extended all over the country and that each ethnic group has its own specific characteristics could explain why there is so little information about the health of the indigenous people in Brazil.

It is usually reported that when an indigenous population gets closer to the lifestyle and culture of those in urban areas, changes in their way of life are observed, especially in diet ${ }^{6,8}$. Although there is still little information on the oral health status of most indigenous ethnic groups in Brazil, recent reports show that native individuals have undergone modifications in their oral health epidemiological profiles as a result of socioeconomic, cultural, and environmental changes ${ }^{8-11}$.
It is known that dental caries remain one of the most relevant oral health problems affecting individuals from different age groups all over the world ${ }^{10}$, including indigenous populations ${ }^{11}$. Studies have reported high rates of caries in indigenous children, adolescents, and adults ${ }^{12-15}$. About $93 \%$ of children aged 6-12 years from the Xakriabá ethnic group from Sumaré were found to have cavitated lesions in the primary dentition, and $17 \%$ already had lesions in the permanent dentition ${ }^{16}$.

Another survey performed in the Xingu area with the Kaiabi indigenous people showed that children at the age of 5 had a mean decayed, missing, and filled teeth (dmft) index of $8.22^{17}$, much higher than the national average. Moreover, it has been observed that as age increases, the prevalence of caries also increases, as shown by Deeley et al. ${ }^{18}$, who found a mean DMFT in$\operatorname{dex} \geq 20$ in a population of indigenous individuals whose ages varied from 14 to 42 years.

In addition, studies have shown that oral health inequalities exist when comparing access to oral health care and regular oral health education and disease prevention programs between indigenous and non-indigenous individuals. In fact, investigations have shown that indigenous populations are more vulnerable to the occurrence of dental caries and their consequences ${ }^{11,19}$.

National health surveys conducted with a large number of people use of combination of several probability methods to select the sample, so that it representative of the entire population. This combination of methods is called sampling complex design ${ }^{20}$. Several studies have been conducted with the purpose of showing the problems of not considering the sampling plan design when analyzing the data and that sampling by clusters, in general, leads to a loss of precision in the estimation of the averages ${ }^{20,21}$.

Once all these arguments are analyzed in conjunction, it is evident that an epidemiological survey specifically designed for the Brazilian indigenous population is needed. However, while such a study is not available, and considering that the National Oral Health Survey (SB Brasil 2010) conducted by the Ministry of Health during the years 2009 and 2010 was an attempt to understand the epidemiological oral health profile of the Brazilian population, including people who declared themselves as indigenous, it is believed that the analysis of these data might shed some light on the issue.

Therefore, the aim of the current study was to compare the prevalence of caries and the mean 
number of decayed, missing, and filled teeth between indigenous and non-indigenous individuals from different age groups, based upon the information retrieved from the SB Brasil 2010 database, as well as to understand the effect of sample weights and complex sample designs in the SB Brasil outcomes.

\section{Materials and methods}

The methodology involved a cross-sectional study design in which a descriptive analysis was performed using the National Oral Health (SB Brasil 2010) database. The present investigation focused on dental caries among self-identified indigenous individuals and non-indigenous individuals of urban areas in Brazil.

All information was obtained, upon formal request, from the National Coordination of Oral Health. It has obtained the written consent of all participants or parents/guardians in participants who were under 18 years. The reference database contained no identifiers that could be used to directly recognize the individuals assessed.

Due to the size of Brazil and its cultural and economic diversity among geographical regions, the SB Brasil 2010 used the regional division as the first stratification. The complex sampling design was composed of 32 domains in which each state capital (26 states and the Federal District) counted as one domain, plus the five national geographic administrative regions (North, Northeast, South, Southeast, and Midwest). In the end, 177 municipalities were included in the survey, as follows: the 26 state capitals and the Federal District, in addition to 150 municipalities randomly selected from all over the country. The kappa coefficient weighted for each examiner, age group and studied grievance, was established with the value of 0.65 as a minimum acceptable limit. Detailed information about the SB Brasil 2010 methodology is available elsewhere ${ }^{22}$.

A total of 37,519 subjects were examined at their places of residence and also replied to a structured questionnaire composed of three sections that aimed to assess socioeconomic status, level of education, use of dental services, and self-perception regarding oral health. With respect to skin color, the methodology followed the self-classification used by the Brazilian Institute of Geography and Statistics $(\mathrm{IBGE})^{7}$ in which the following options are possible: white, brownskinned, black, yellow, and indigenous. The composition of the sample by age and age groups was determined in accordance with World Health Organization (WHO) recommendations; each has its epidemiological importance: Individuals aged 5 and 12 years and those belonging to the age groups 15-19 years, 35-44 years, and 65-74 years ${ }^{23}$.

For the present investigation, subjects were categorized as indigenous or non-indigenous, and only variables associated with dental caries were analyzed. In addition, the index most commonly used worldwide to evaluate caries experience, suggested by the WHO, which is the registration of $\mathrm{D} / \mathrm{d}$ (decayed), $\mathrm{M} / \mathrm{m}$ (missing), and $\mathrm{F} / \mathrm{f}$ (filled) components, was used in the SB Brasil 2010 survey associated with the assessment of treatment needs and the diagnosis of root caries.

Due to the large ethnicity diversity in the sample collected for the study, a multivariate analysis was also performed considering sample weights and the effect of the complex sample design. The dependent variables were: number of healthy teeth, decayed, missing and filled teeth, and DMFT and dmft indexes. The independent variables were: ethnicity (white, black, indigenous, yellow, and brown), age/age-groups (5, 12, 1519, 35-44, 65-74), administrative region (North, Northeast, Southeast, South and Midwest), years of schooling (1-4,5-9 and $\geq 10$ ), gender (male and female), and family income $(\leq \mathrm{R} \$ 1500,00$ and $>$ $\mathrm{R} \$ 1500,00$ ) (Values in Reais. In July of 2015, \$1 American Dollar was R\$3.32 Reais).

The $\mathrm{dmft} / \mathrm{DMFT}$ index is a continuous variable, which is calculated by the ratio of the number of decayed, missing, and filled teeth to the total number of teeth examined. The dmft term is used for the primary dentition and the DMFT for permanent dentition.

The DMFT index was calculated for 12-yearold children and those in the age groups 15-19 years, 35-44 years, and 65-74 years. In the analysis, the DMFT index dichotomous form (DMFT $=0$ versus DMFT $\neq 0$ ) was used. The non-parametric Kolmogorov-Smirnov test ruled out normal distribution of the studied variables. The Kruskal-Wallis test was used when more than two categories were being analyzed, and Wilcoxon Scores (Rank Sums) were used when only two categories were analyzed. When the variable $\mathrm{dmft}$ and DMFT were analyzed in a dichotomous way, logistic regression was performed.

Sample weights and the effect of complex sample designs related to standard errors were treated using the procedure "proc surveyreg" SAS. Multiple linear regression models were used for each of the dependent variables (number of 
healthy teeth decayed, missing and filled, and DMFT and $\mathrm{dmft}$ ).

Data analysis was conducted using the Statistical Analysis System (SAS) Package (SAS 9.2 and 9.4 for Windows, SAS Institute Inc., Cary, NC, USA) with a $95 \%$ confidence interval (CI) applied to statistical tests and hypotheses.

The 2010 SB Brazilian Oral Health Survey, which followed the standards required by the Declaration of Helsinki, was approved by the National Council for Ethics in Research. However, in this study only the 2010 SB Brasil data were used, not having access to the names of the participants.

\section{Results}

A total of 37,519 individuals ( $98.36 \%$ of the estimated sample) were evaluated, among whom 308 self-identified themselves as indigenous $(0.82 \%)$. The majority of the sample was composed of females, for both indigenous (52.92\%) and non-indigenous $(57.20 \%)$ individuals, distributed in five age brackets. Regarding income and level of education, it was observed that most of the indigenous and non-indigenous individuals had studied for 4-7 years and had household incomes varying from $R \$ 501.00$ to $R \$ 1,500.00$. (Values in Reais. In July of 2015, \$1 American Dollar was R\$3.32 Reais) (Table 1).

When not taking into account the sampling weight, the prevalence of caries among 5-yearold indigenous and non-indigenous children was $69.2 \%$ and $54.0 \%$, respectively. The mean $\mathrm{dmft}$ index for non-indigenous children was $2.41 \pm$ 3.35 , and for indigenous children was $4.02 \pm 4.01$ $(\mathrm{z}=3.13, \mathrm{p}=0.0017)$. The mean $\mathrm{dmft}$ index was mainly attributed to the "d" component for both ethnic groups, as both the " $\mathrm{m}$ " and " $\mathrm{f}$ " components were almost nonexistent. Indigenous children had fewer healthy teeth, more decayed teeth, and fewer restored teeth than non-indigenous children (Table 2).

The logistic regression analysis showed that indigenous children are more likely to have a $\mathrm{dmft}$ different from zero than non-indigenous children (primary teeth) after controlling for gender and domain (capital or interior) (odds ratio: 1.41 ; 95\% CI: 0.463 - 4.275).

When considering the sampling weight and the effect of the complex sample design, the number of sound primary teeth among five-years-old indigenous children was significantly lower than in children from other ethnic groups (Table 3).

When the elements, decayed and filled, were analyzed, the results did not show a statistically significant difference. Indigenous children aged five had fewer missing teeth than white, black and brown ethnics. When the $\mathrm{dmft}$ index was analyzed among children across different regions, it did not differ significantly among ethnic groups, though the northern region had a significantly higher $\mathrm{dmft}$ compared to the southeast $(\mathrm{p}<$ 0.0001 ), being this variable also higher among males $(\mathrm{p}=0.0008)$ and those with a household income $<\mathrm{R} \$ 1,500.00(\mathrm{p}<0.0001)$ (Table 3).

Our results showed that the most prevalent component of the DMFT index in individuals aged 5, 12, and 15-19 years was the "D" component, while for those aged 35-44 and 65-74 years, the "M" component was the most prevalent. A statistically significant difference between the mean DMFT index of indigenous and non-indigenous individuals was observed only for the 5 -year-old group. However, when the DMFT components were analyzed separately, it was noted that indigenous individuals at the ages of 5, 35-44, and 65-74 presented with more decayed teeth than their counterparts. Except for the group of 65-74-year-olds, native individuals were found to have more missing teeth than did non-indigenous individuals. In addition, in all age groups, the native individuals had fewer restored teeth than non-indigenous individuals (Table 4).

When performing a multivariate analysis considering the sample weights and the effect of the complex sample design, the indigenous presented a greater number of sound teeth than the white, yellow and brown ethnics, though the numbers were not statistically different from the black ethnic. The DMFT in the indigenous population was significantly lower than in the yellow and brown ethnic groups $(\mathrm{p}=0.0474, \mathrm{p}$ $=0.0488$ ), but not significantly different than the white and black ethnicity (Table 5). Among the administrative regions, the North presented a DMFT higher than the Southeast. The individuals with family income $\leq \mathrm{R} \$ 1,500.00$ were those with fewer decayed and filled teeth, but with more missing teeth. When gender was analyzed, men had a larger number of decayed teeth, while women had a greater number of filled and missing teeth, thus showing a significantly higher DMFT than women. 
Table 1. Characterization of the sample considering the indigenous and non-indigenous groups by gender, age, years of education, and family income

\begin{tabular}{|c|c|c|c|c|}
\hline \multirow{2}{*}{ Variables } & \multicolumn{2}{|c|}{ Indigenous } & \multicolumn{2}{|c|}{ Non-indigenous } \\
\hline & number & Percentage & number & Percentage \\
\hline Total & 308 & $0.82 \%$ & 37,211 & $99.18 \%$ \\
\hline \multicolumn{5}{|l|}{ Gender } \\
\hline Female & 163 & $52.92 \%$ & 21,270 & $57.16 \%$ \\
\hline Male & 145 & $47.08 \%$ & 15,941 & $42.84 \%$ \\
\hline \multicolumn{5}{|l|}{ Age Group } \\
\hline 5 years & 53 & $17.20 \%$ & 7,286 & $19.60 \%$ \\
\hline 12 years & 62 & $20.12 \%$ & 7,266 & $19.53 \%$ \\
\hline $15-19$ years & 49 & $15.90 \%$ & 5,396 & $14.50 \%$ \\
\hline $35-44$ years & 72 & $23.37 \%$ & 9,707 & $26.09 \%$ \\
\hline $65-74$ years & 72 & $23.38 \%$ & 7,547 & $20.28 \%$ \\
\hline \multicolumn{5}{|l|}{ Years of Education } \\
\hline $0-3$ years & 81 & $28.22 \%$ & 10,349 & $28.67 \%$ \\
\hline $4-7$ years & 119 & $41.50 \%$ & 11,966 & $30.06 \%$ \\
\hline $8-11$ years & 71 & $24.73 \%$ & 9,923 & $27.41 \%$ \\
\hline $12-15$ years & 16 & $5.60 \%$ & 3,928 & $10.85 \%$ \\
\hline \multicolumn{5}{|l|}{ Family Income $e^{\star}$} \\
\hline $\mathrm{R} \$ 0-250$ & 18 & $6.25 \%$ & 1,194 & $3.35 \%$ \\
\hline $\mathrm{R} \$ 251-500$ & 57 & $19.79 \%$ & 4,800 & $13.47 \%$ \\
\hline $\mathrm{R} \$ 501-1,500$ & 156 & $54.16 \%$ & 18,754 & $52.62 \%$ \\
\hline $\mathrm{R} \$ 1,501-2,500$ & 37 & $12.84 \%$ & 6,195 & $17.38 \%$ \\
\hline $\mathrm{R} \$ 2,501-4,500$ & 13 & $4.51 \%$ & 2,971 & $8.34 \%$ \\
\hline $\mathrm{R} \$ 4,501-9,500$ & 4 & $1.40 \%$ & 1,218 & $3.42 \%$ \\
\hline More than 9,500 & 3 & $0.59 \%$ & 509 & $1.43 \%$ \\
\hline
\end{tabular}

Table 2. Mean decayed, missing, and filled teeth ( $\mathrm{dmft})$ index in primary dentition of 5-year-old indigenous and non-indigenous children, without using sample weights.

\begin{tabular}{rlrrrrrrr}
\hline Age & \multicolumn{1}{c}{ Ethnic Group } & \multicolumn{1}{c}{ n } & Sound & decayed & missing & filled & Mean dmft & DP \\
\hline \multirow{5}{*}{5 years } & Indigenous & 52 & 14.81 & 3.87 & 0.02 & 0.13 & 4.02 & 4.01 \\
& Non-indigenous & 7295 & 16.68 & 2.06 & 0.06 & 0.29 & 2.41 & 3.35 \\
& Total & 7347 & 16.67 & 2.08 & 0.06 & 0.29 & 2.42 & 3.36 \\
& $p$ & & $\mathbf{0 . 0 0 2 8}$ & $\mathbf{0 . 0 0 0 8}$ & 0.5736 & 0.0902 & $\mathbf{0 . 0 0 1 7}$ & \\
\hline
\end{tabular}

\section{Discussion}

In Brazil, tooth decay remains the main oral health problem, although a worldwide decline of the disease in children and adolescents has been observed $^{24}$. Even though the presence of active lesions is less common among adults and the elderly, the consequences of the disease are still evident in those groups.
The SB Brasil 2010 survey conducted by the Ministry of Health aimed to assess the oral health status of the Brazilian population, but the survey was not specifically developed for the indigenous population. It is also important to highlight that the results presented herein are based on a secondary analysis. However, due to the lack of population-based studies among the Brazilian indigenous population, it was considered worth- 
Table 3. Multivariate analysis using sample weight and considering the effect of the sample design, in 5 years-old group.

\begin{tabular}{|c|c|c|c|c|c|c|c|c|c|c|}
\hline \multirow[b]{2}{*}{$\begin{array}{l}\text { Ethnic } \\
\text { Group }\end{array}$} & \multicolumn{2}{|c|}{ Sound } & \multicolumn{2}{|c|}{ decayed } & \multicolumn{2}{|c|}{ missing } & \multicolumn{2}{|c|}{ filled } & \multicolumn{2}{|c|}{$\mathrm{dmft}$} \\
\hline & $\beta$ & $\begin{array}{c}\text { p-value } \\
\beta\end{array}$ & $\beta$ & $\begin{array}{c}\text { p-value } \\
\beta\end{array}$ & $\beta$ & $\begin{array}{c}\text { p-value } \\
\beta\end{array}$ & $\beta$ & $\begin{array}{c}\text { p-value } \\
\beta\end{array}$ & $\beta$ & $\begin{array}{c}\text { p-value } \\
\beta\end{array}$ \\
\hline $\begin{array}{l}\text { White vs } \\
\text { Indigenous }\end{array}$ & 7.3486236 & 0.0083 & -1.0838935 & 0.1518 & 0.0516526 & 0.0011 & 0.1375072 & 0.5352 & -0.7732292 & 0.3970 \\
\hline $\begin{array}{l}\text { Black vs } \\
\text { indigenous }\end{array}$ & 5.6321363 & 0.0481 & -0.2352050 & 0.7583 & 0.1114160 & $<.0001$ & 0.0557356 & 0.7911 & 0.0208193 & 0.9819 \\
\hline $\begin{array}{l}\text { Yellow vs } \\
\text { indigenous }\end{array}$ & 5.5794003 & 0.0196 & 0.1001218 & 0.9342 & 0.2311222 & 0.1433 & 0.1608385 & 0.4939 & 0.5584809 & 0.6991 \\
\hline $\begin{array}{l}\text { Brown vs } \\
\text { Indigenous }\end{array}$ & 6.7156188 & 0.0148 & -0.4927841 & 0.5214 & 0.0516526 & 0.0011 & 0.1586917 & 0.4337 & -0.1692245 & 0.8509 \\
\hline
\end{tabular}

Table 4. Mean Decayed, Missing, and Filled teeth (DMFT) index among indigenous and non-indigenous individuals by age, according to the $S B$ Brasil 2010, without using sample weights.

\begin{tabular}{|c|c|c|c|c|c|c|c|c|}
\hline Age Group & Ethnic Group & $\mathbf{n}$ & Sound & Decayed & Missing & Filled & DMFT & $\mathrm{DP}$ \\
\hline \multirow[t]{3}{*}{5 years } & Indigenous & 52 & 1.44 & 0.29 & 0.10 & 0.06 & 0.44 & 1.83 \\
\hline & Non-indigenous & 7165 & 1.41 & 0.06 & 0.01 & 0.00 & 0.07 & 0.59 \\
\hline & $p$ & & 0.6153 & 0.0203 & 0.0150 & $<.0001$ & 0.0356 & \\
\hline \multirow[t]{3}{*}{12 years } & Indigenous & 61 & 22.95 & 1.00 & 0.13 & 0.51 & 1.64 & 2.28 \\
\hline & Non-indigenous & 7186 & 23.44 & 1.30 & 0.11 & 0.67 & 2.08 & 2.79 \\
\hline & $p$ & & 0.2995 & 0.2017 & 0.2666 & 0.5639 & 0.1755 & \\
\hline \multirow[t]{3}{*}{$15-19$ years } & Indigenous & 48 & 24.79 & 1.92 & 0.44 & 0.85 & 3.21 & 3.46 \\
\hline & Non-indigenous & 5319 & 23.95 & 1.95 & 0.42 & 2.01 & 4.38 & 4.40 \\
\hline & $p$ & & 0.3725 & 0.4156 & 0.3598 & 0.0017 & 0.0984 & \\
\hline \multirow[t]{3}{*}{$35-44$ years } & Indigenous & 71 & 12.96 & 2.61 & 9.51 & 4.99 & 17.10 & 7.34 \\
\hline & Non-indigenous & 9493 & 13.61 & 2.27 & 8.17 & 6.45 & 16.89 & 7.27 \\
\hline & $p$ & & 0.4285 & 0.0834 & 0.0386 & 0.0287 & 0.7199 & \\
\hline \multirow[t]{4}{*}{ 65-74 years } & Indigenous & 71 & 5.36 & 0.94 & 23.68 & 0.71 & 25.33 & 8.49 \\
\hline & Non-indigenous & 7437 & 3.98 & 0.82 & 24.54 & 1.67 & 27.03 & 6.83 \\
\hline & $p$ & & 0.1342 & 0.4868 & 0.5302 & 0.1671 & 0.2221 & \\
\hline & Indigenous & 308 & 13.06 & 1.38 & 7.94 & 1.58 & 10.90 & 11.69 \\
\hline \multirow[t]{2}{*}{ Total } & Non -indigenous & 37211 & 12.70 & 1.30 & 7.19 & 2.44 & 10.93 & 11.58 \\
\hline & $p$ & & 0.5706 & 0.1421 & 0.2395 & 0.0012 & 0.9878 & \\
\hline
\end{tabular}

while to interpret the findings obtained by means of the SB Brasil 2010.

It is noteworthy that the authors have discussed about the validity of inferences using the SB Brazil data (2003) without taking into account the effect of the complex sample design and without using sample weights ${ }^{25}$. As a justification, the authors who participated in the planning and execution of the National Search and generated the database, performed a balancing test and argued that the data is valid, as few differences were found with and without the weighting ${ }^{26}$. In an attempt to correct the failures presented in SB Brazil 2003,the Survey Epidemiologic SB Brazil 2010 used sample weights and took into account the effect of sample design complex.

Another limitation of the current study relates to the fact that the SB Brasil 2010 investigated only individuals residing in urban areas. According to the latest National Demographic Census, the majority of the indigenous population $(63.8 \%)$ lives in rural areas ${ }^{27}$. Thus, in future 
Table 5. Multivariate analysis using sample weight and considering the effect of the sample design.

\begin{tabular}{|c|c|c|c|c|c|c|c|c|c|c|}
\hline & Sound & & Decayed & & Missing & & Filled & & DMFT & \\
\hline & $\beta$ & $\begin{array}{c}\text { p-value } \\
\beta\end{array}$ & $\beta$ & $\begin{array}{c}\text { p-value } \\
\beta\end{array}$ & $\beta$ & $\begin{array}{c}\text { p-value } \\
\beta\end{array}$ & $\beta$ & $\begin{array}{c}\text { p-value } \\
\beta\end{array}$ & $\beta$ & $\begin{array}{c}\text { p-value } \\
\beta\end{array}$ \\
\hline \multicolumn{11}{|l|}{ Ethnic Group } \\
\hline $\begin{array}{l}\text { White vs } \\
\text { Indigenous }\end{array}$ & $-1,57$ & 0.0488 & -0.2737529 & 0.3407 & 0.745393 & 0.4094 & 0.7638581 & 0.2242 & 1.235499 & 0.1028 \\
\hline $\begin{array}{l}\text { Black vs } \\
\text { indigenous }\end{array}$ & $-1,03$ & 0.2253 & 0.0168930 & 0.9565 & 0.815049 & 0.3854 & 0.0341286 & 0.9553 & 0.866070 & 0.2858 \\
\hline $\begin{array}{l}\text { Yellow vs } \\
\text { indigenous }\end{array}$ & $-2,38$ & 0.0091 & 0.3695172 & 0.4704 & 0.742902 & 0.4702 & 0.7238912 & 0.3849 & 1.836310 & 0.0474 \\
\hline $\begin{array}{l}\text { Brown vs } \\
\text { Indigenous }\end{array}$ & $-1,55$ & 0.0045 & -0.2000043 & 0.4816 & 0.736843 & 0.3835 & 0.8310903 & 0.1895 & 1.367929 & 0.0488 \\
\hline \multicolumn{11}{|l|}{ Family income } \\
\hline $\begin{array}{l}\leq \mathrm{R} \$ 1500,00 \\
\text { vs }>1500,00\end{array}$ & $-0,32$ & 0.0796 & 0.6214440 & $<.0001$ & 1.007970 & $<.0001$ & -0.9544009 & $<.0001$ & 0.675014 & 0.0012 \\
\hline \multicolumn{11}{|l|}{ Years of Education } \\
\hline None vs $>10$ & $-2,11$ & $<0.0001$ & 0.8541610 & $<.0001$ & 5.096844 & $<.0001$ & -3.3404519 & $<.0001$ & 2.610553 & $<.0001$ \\
\hline 1 a 4 vs $>10$ & $-1,91$ & $<0.0001$ & 0.8544223 & $<.0001$ & 4.366731 & $<.0001$ & -2.9847516 & $<.0001$ & 2.236401 & $<.0001$ \\
\hline 5 a 9 vs $>10$ & $-1,09$ & $<0.0001$ & 0.6380704 & $<.0001$ & 2.233443 & $<.0001$ & -1.5351095 & $<.0001$ & 1.336404 & $<.0001$ \\
\hline \multicolumn{11}{|l|}{ Gender } \\
\hline Male vs female & 0,99 & $<0.0001$ & 0.1852132 & 0.0024 & -0.817936 & $<.0001$ & -0.3497096 & 0.0020 & -0.982433 & $<.0001$ \\
\hline
\end{tabular}

surveys, it would be important to also include this portion of the indigenous population, so as to ascertain their oral health status and needs in order to determine whether the findings obtained for the indigenous residents in urban areas are comparable to those for residents from rural areas.

Another aspect that should be taken into account relates to the manner in which the indigenous population was defined. It is important to conduct an anthropological discussion in these types of study, as many authors use the terms interchangeably races and ethnicities ${ }^{28}$, though race has been associated much more with social characteristics of the individual rather than with biological characteristics. In fact, the term ethnicity refers to the individual who belongs or is believed to belong to a group in which has similar characteristics and geographical ancestry, especially the cultural traditions and language ${ }^{3}$. The SB Brasil 2010 methodology adopted self-declaration as the instrument to define ethnicity, which is in line with the trend observed most recently in health care ${ }^{22}$.

Therefore, it is believed that the SB Brasil 2010 was fairly well able to classify individuals into different ethnic groups. Nevertheless, the results that will be discussed below should be viewed with caution, because they are related to a well-defined group of indigenous individuals living in urban areas. This means that there are limitations regarding the inferences and possible generalizations of the results presented here for the entire Brazilian indigenous population.

The $\mathrm{dmft} / \mathrm{DMFT}$ index is a continuous variable, which is calculated by the ratio of the number of decayed, missing, and filled teeth to the total number of teeth examined. The $\mathrm{dmft}$ term is used for the primary dentition and the DMFT is for permanent dentition. It is a reliable indicator that measures the oral health of individuals in relation to both dentitions ${ }^{1}$. Moreover, all previous national surveys ${ }^{29}$ and many international ones ${ }^{30}$ used the DMFT index to report dental caries status, facilitating the comparison among studies carried out among different populations.

Regarding the percentage of 5-year-old children free of caries, it was observed that this was higher in non-native children. When indigenous children are compared with each ethnic group separately, the indigenous people show less healthy teeth than others. The same results had already been observed in the SB Brasil $2003^{31}$. However, even for non-native children, the percentage of caries-free individuals at that age, which was $30.8 \%{ }^{32}$, still fell well short of the 
target set by WHO for the year 2000, which was $50 \%$. This scenario might be even worse when studies conducted directly with indigenous residents on Indians reservations are taken into account. According to Sampaio et al., who carried out a survey at the Potiguara Indian reservation, only $12.7 \%$ of children (5 years-old) were caries-free. Thus, diet, lack of education regarding oral health, and the lack of dental care may further aggravate the situations of the individuals who live in such conditions, which may partly explain these findings ${ }^{8}$.

As for the permanent dentition, the results were expressed by the DMFT, which has a cumulative character over all the years. The DMFT at 12 years old is used internationally to evaluate the early caries attack rate in the permanent dentition $^{29}$.Regarding the percentage of individuals free of caries at this age, no difference was observed when the two populations were compared without sample weight. Although the number of children free of caries was greater than that found in the SB Brasil 2003 survey, these data should be analyzed with caution since the epidemiological survey in 2010 was conducted only in urban areas, where there are more health care services. Thus, this result may reflect a possible selection bias.

WHO recommended, for children at 12 years of age, that the DMFT index should not be greater than 3 in the year 2000 (Dental Federation, $1982)^{33}$. In the present study, the mean DMFT observed among indigenous individuals at this age was $45.3 \%$ below this value (1.64), which can be considered an important step forward, especially if these results are compared with previous studies that show a worse scenario ${ }^{10,30-32}$.

Regarding the inclusion of DMFT index for 5-year-old children, questions are raised as to whether the values found are actually as significant as those obtained for older groups, since few permanent teeth are present for the evaluation, and these have been in the oral cavity for a very short period. Nevertheless, even with few teeth for analysis, a statistical difference was observed between indigenous and non-indigenous individuals, indicating that indigenous children might undergo greater exposure to caries risk factors at an early stage, without taking into account the sample weight and the sample design complex.

The percentage distribution of DMFT components showed that, in general, individuals younger than 19 years of age presented with more decayed teeth, while those older than 19 years presented with more missing teeth. This is due to the cumulative burden of disease and decay over the years, and could also be observed in the SB Brasil 2003 survey $^{31}$.

Indigenous individuals at the age of 5 years and in the age groups of 35-44 and 65-74 years have more decayed teeth than non-indigenous individuals. However, native individuals have also lost more teeth than non-indigenous individuals, in almost all age groups, and have fewer restored teeth, without considering the sample weight and the sample design complex. These results are similar to those found in the literature $^{30,32}$, and indicate that there is a lack of prevention programs and oral health promotion programs for this population, such as the spread of the regular practice of tooth brushing and the use of fluoride toothpastes. Neither are there public policies aimed at solving the problems already established ${ }^{32}$.

The results presented herein should be analyzed from different perspectives. By merely observing the $p$ values, one might have the impression that the prevalence of caries in indigenous individuals is quite similar to that in non-indigenous individuals, with the exception of 5-yearolds and one may believe that both groups have the same access to oral health services. However, when the DMF is decomposed, it is obvious that the indigenous individuals are undergoing many more tooth extractions at an early age, particularly those in the 35-44-year-old age group, than the non-indigenous individuals, which might be associated with a delay in receiving dental care. This is a very interesting result, as tooth loss is considered a marker of inequality in oral health ${ }^{34}$ that clearly reinforces the idea that indigenous individuals are much more vulnerable than non-indigenous individuals regarding oral health problems. Similar results were obtained when black and brown-skinned subjects were compared to white subjects, with the number of teeth restored and/or rehabilitated statistically higher for the white population ${ }^{35}$.

The analysis of the sample weight and the complex sample design showed more healthy teeth among indigenous people than among white, yellow and brown ethnic groups from urban areas $(\mathrm{p}=0.0488, \mathrm{p}=0.0091$ and $\mathrm{p}=0.0045)$. These results differ from the ones in which the indigenous population lives in indigenous lands ${ }^{8}$.

Regarding the association between DMFT index and family income, plus years of study, the study showed a greater number of teeth restored between people with a higher income and a high number of missing teeth among individuals with 
lower income. This could be the result of several factors, such as the difficulty of access or lack of information about the importance of teeth. It is important to emphasize that these analysis were performed with the entire studied population and all age groups.

Moreover, in regard to the SB Brasil 2010 results, it is important to emphasize that they are restricted to indigenous individuals living in urban areas, whose experience might be very different from the reality of those who reside on Indian reservations and who still constitutes the majority in Brazil. Unfortunately, however, it is difficult to draw a parallel of the caries status of indigenous individuals investigated by the $\mathrm{SB}$ Brasil 2010 with the situation of the indigenous individuals residing in rural areas. According to a systematic review published in $2014^{30}$, no studies have been carried out aiming to investigate caries in the indigenous adult and elderly population in Brazil. The majority of the studies included in the review were conducted in children, and a few were performed in adolescents.

In overall, the results of the present investigation show that disparities in oral health between indigenous and non-indigenous individuals begin at a very young age, and extend throughout life, confirming the cumulative aspect of dental caries but, in this case, being more pronounced for the indigenous individuals. Therefore, these findings should be considered as an alert to the oral health authorities, indicating that there is an urgent need to conduct an investigation that includes a representative sample from all the ethnic groups that are spread over the country in both urban and rural areas. Without that, it is impossible to have a fair picture of the oral health status of these populations, rendering very difficult the development of programs that can effectively deal with their specific problems.

The results of this study lend credence to suspicions that in Brazil there are unequal differences in the state of tooth decay between self-identified indigenous individuals and their respective national counterparts living in urban areas. In addition, the findings shed a light into the need of conducting an oral health epidemiological survey exclusively among indigenous people living in indigenous lands, so that the data found in this study is as closer as possible to reality.

\section{Collaborations}

KCO Miranda, TAC Souza and SC Leal have made substantive contribution to the study and all have reviewed the final version of the manuscript and approved its submission.

\section{Referências}

1. United Nations. Department of economic and social affairs. Workshop on data collection and disaggregation for indigenous peoples. The concept of indigenous peoples. New York. 19-21. January 2004.

2. Brasil. Lei no 6.001, de 19 de dezembro de 1973. Dispõe sobre o Estatuto do Índio. Diário Oficial da União 1973; $21 \mathrm{dez}$.

3. Bhopal R. Glossary of terms relating to ethnicity and race: for reflection and debate. J Epidemiol Community Health 2004; 58(6):441-445.

4. Travassos C, Williams DR. The concept and measurement of race and their relationship to public health: a review focused on Brazil and the United States. Cad Saude Publica 2004; 20(3):660-678.

5. Sousa MC, Scatena JHG, Santos RV. O Sistema de Informação da Atenção à Saúde Indígena (SIASI): criação, estrutura e funcionamento. Cad Saude Publica 2007; 23(4):853-861.

6. Arantes R, Santos RV, Frazão P. Diferenciais de cárie dentária entre os índicos Xavantes de Mato Grosso, Brasil. Rev Bras Epidemiol 2010; 13(2):223-236.

7. Instituto Brasileiro de Geografia e Estatística (IBGE) Sinopse do Censo Demográfico 2010. Rio de Janeiro: IBGE; 2011. 
8. Sampaio FC, Freitas CHSM, Cabral MBF, Machado ATAB. Dental caries and treatment needs among indigenous people of the Potiguara Indian reservation in Brazil. Rev Panam Salud Publica 2010; 27(4):246-251.

9. Carneiro MCG, Santos RV, Garnelo L, Rebelo MAB, Coimbra Júnior CEA. Cárie Dentária e Necessidade de Tratamento Odontológico entre os Índios Baniwa do Alto Rio Negro, Amazonas. Cien Saude Colet 2008; 13(6):1985-1992.

10. Marcenes W, Kassebaum NJ, Bernabé E, Flaxman A, Naghavi M, Lopez A, Murray CJ. Global burden of oral conditions in 1990-2010: a systematic analysis. J Dent Res 2013; 92(7):592-597.

11. Mejia GC, Parker EJ, Jamieson LM. An introduction to oral health inequalities among Indigenous and non-Indigenous populations. Int Dent J 2010; 60(3 Supl. 2):212-215.

12. Dumont AFS, Salla JT, Vilela MB, Morais PC, Lucas SD. Rate of dental treatment needs: the case of the Xakriaba Indians. Cien Saude Colet 2008; 13(3):1017-1022.

13. Nascimento S, Scabar LF. Levantamento epidemiológico de cárie, utilizando os índices CPO-D, ceo-d e IHOS, nos índios da aldeia Wakri no Estado do Pará. Rev Inst Ciênc Saúde 2008; 26(2):247-254.

14. Arantes R, Santos RV, Frazão P, Coimbra Júnior CEA. Caries, gender and socio-economic change in the Xavante Indians from Central Brazil. Ann Hum Biol 2009; 36(2):162-175.

15. Alves Filho P, Santos RV, Vettore MV. Saúde bucal dos índios Guarani no estado do Rio de Janeiro, Brazil. Cad Saude Publica 2009; 25(1):37-46.

16. Diab AD, Lucas SD. Cárie dentária em crianças indígenas Xakriabá. Epidemiol Serv Saude 2008; 17(2):149153.

17. Detogni AM. De volta às origens. Rev $A B O N a c$ 1994; 2(3):138-148.

18. Deeley K, Letra A, Rose EK, Brandon CA, Resick JM, Marazita ML, Vieira AR. Possible association of amelogenin to high caries experience in a Guatemalan-Mayan population. Caries Res 2008; 42(1):8-13.

19. Alves Filho P, Santos RV, Vettore MV. Desigualdades socioambientais na ocorrência de cárie dentária na população indígena no Brasil: evidências entre 2000 e 2007. Rev Bras Epidemiol 2013; 16(3):692-704.

20. Szwarcwald CL, Damacena GN. Complex Sampling Design in Population Surveys: Planning and effects on statistical data analysis. Rev Bras Epidemiol 2008; 11(Supl. 1):38-45.

21. Sousa MH, Silva NN. Estimatives from a complex survey. Rev Saude Publica 2003; 37(5):662-670.

22. Roncalli AG, Silva NN, Nascimento AC, Freitas CHSM, Casotti E, Peres KG, Moura L, Peres MA, Freire MCM, Cortes MIS, Vettore MV, Paludetto Júnior M, Figueiredo N, Goes PSA, Pinto RS, Marques RAA, Moysés SJ, Reis SCGB, Narvai PC. Aspectos metodológicos do Projeto SB Brasil 2010 de interesse para inquéritos nacionais de saúde. Cad Saude Publica 2012; 28(Supl.):40-57.
23. World Health Organization (WHO). Calibration of examiners for oral health epidemiological surveys. Geneva: ORH/EPID; 1993.

24. Narvai PF, Frazão P, Roncalli AG, Antunes JLF. Cárie dentária no Brasil: declínio, polarização, iniquidade e exclusão social. Rev Panam Salud Publica 2006; 19(6):385-393.

25. Queiroz RCS, Portela MC, Vasconcelos MTL. Brazilian Oral Health Survey (SB Brazil 2003): data do not allow for population estimatives, but correction is possible. Cad Saude Publica 2009;25(1):47-58.

26. Narvai PC, Antunes JL, Moysés SJ, Frazão P, Peres MA, Peres KG, Sousa ML, Roncalli AG. Scientific validity of epidemiological knowledge based on data from the Brazilian Oral Health Survey (SB Brazil 2003). Cad Saude Publica 2010, 26(4):647-670.

27. Brasil. Ministério da Saúde (MS). Pesquisa Nacional de Saúde Bucal 2010. Brasília: MS; 2012.

28. Kaplan JB, Bennet T. Use of race and ethnicity in biomedical publication. JAMA 2003; 289(20):2709-2716.

29. Arantes R, Santos RV, Coimbra Júnior CEA. Oral health among the Xavánte Indians in Pimentel Barbosa, MatoGrosso, Brazil. Cad Saude Publica 2001; 17(2):375-384.

30. Alves Filho P, Santos RV, Vettore MV. Fatores associados a cárie dental e doença periodontal em indígenas na América Latina: Revisão sistemática. Rev Panam Salud Publica 2014; 35(1):67-77.

31. Coelho de Souza TA. Oral health disparities among the indigenous people in Brazil. [thesis]. Lexington: University of Kentucky; 2009.

32. Rigonatto DDL, Antunes JLF, Frazão P. Dental caries experience in Indians of the Upper Xingu, Brazil. Rev Inst Med Trop 2001; 43(2):93-98.

33. Federation Dentaire Internacionale. Global goals for oral health in the year 2000. Int Dent J 1982; 32(1):74-77.

34. Peres MA, Barbato PR, Reis SCGB, Freitas CHSM, Antunes JLF. Tooth loss in Brazil: analysis of the 2010 Brazilian Oral Health Survey. Rev Saude Publica 2013; 47(Supl. 3):1-11.

35. Guiotoku SK, Moysés ST, Moysés SJ, França BHS, Bisinelli JC. Iniquidades raciais em saude bucal no Brasil. Rev Panam Salud Publica 2012; 31(2):135-141.

Artigo apresentado em 19/03/2016

Aprovado em 11/07/2016

Versão final apresentada em 13/07/2016 